\title{
CHEMICAL CONTROL STRATEGIES OF Commelina benghalensis IN COFFEE CROP
}

\author{
Paulo Vinicius da Silva ${ }^{1}$, Gustavo César Barbosa ${ }^{2}$, Andréa Ferrari ${ }^{3}$, \\ Sergio Mateus Tronquini ${ }^{4}$, Patrícia Andrea Monquero ${ }^{5}$
}

(Received: April 07, 2019; accepted: May 27,2019)

\begin{abstract}
The present study aims to evaluate the control of $C$. benghalensis by herbicides applied in post-emergence and in pre-emergence sequentially in the infesting weed in the coffee crop. Two field experiments were carried out in a coffee crop, with natural infestation of $C$. benghalensis, the experimental design of both was completely randomized with 4 replicates. The first experiment, involving a single application of herbicides in post-emergence presented the following treatments: (1) saflufenacil (70 g i.a. ha- ${ }^{-1}$; (2) glufosinate (400 g i.a. ha- ${ }^{-1}$; (3) carfentrazone (20 g i.a. ha $\left.{ }^{-1}\right)$; (4) flumioxazin (120 g i.a. ha' $)$; (5) metsulfuron (6 g i.a. ha $\mathrm{h}^{-1}$ ), and (6) witness (without application of herbicide). In the second experiment, the treatments were: (1) saflufenacil (70 g i.a. ha $\left.\mathrm{g}^{-1}\right)$; (2) carfentrazone (20 g i.a. ha-1); (3) flumioxazin $\left(120 \mathrm{~g}\right.$ i.a. ha $\left.\mathrm{h}^{-1}\right)$; (4) metsulfuron (6 g i.a. ha $\left.^{-1}\right)$, all these treatments with a sequence of indaziflam (75 g i.a. ha $\left.{ }^{-1}\right)$, at 21 days after the application of the treatments (DAT) of pos-emerging; (5) Witness (without application of herbicides). In the first experiment the herbicides safluenacil and flumioxazin presented the best percentages of control in post-emergence with 90 and $85.25 \%$ respectively, at 7 DAT, keeping the control superior to $80 \%$ at 21 DAT. In the second experiment, the treatments saflufenacil and flumioxazin with indaziflam sequential, presented control of $80 \%$ and $82.5 \%$ respectively at 28DAA (Days After Application). The herbicides saflufenacil and fluxioxazin represent an option for the control of $C$. benghalensis in post-emergence and favor the performance of the sequentially applied indaziflam herbicide.
\end{abstract}

Index terms: Weed, herbicide, indaziflam.

\section{ESTRATÉGIAS DE CONTROLE QUÍMICO DE Commelina benghalensis NA CULTURA DO CAFÉ}

\begin{abstract}
RESUMO: O objetivo deste trabalho foi avaliar o controle de $C$. benghalensis através de herbicidas aplicados na pósemergência e em pré-emergência de forma sequencial na planta daninha infestante na cultura do café. Foram realizados dois experimentos em campo em uma lavoura de café, com infestação natural de $C$. benghalensis, o delineamento experimental de ambos foi inteiramente casualizado com 4 repetições. O primeiro experimento, envolvendo uma única aplicação de herbicidas na pós-emergência, apresentou os seguintes tratamentos: (1) saflufenacil (70 g i.a. ha ${ }^{-1}$ ); (2) amônio glufosinato (400 g i.a. ha $\left.{ }^{-1}\right)$; (3) carfentrazone-etílica (20 g i.a. ha $\left.{ }^{-1}\right)$; (4) flumioxazim $\left(120 \mathrm{~g}\right.$ i.a. ha $\left.{ }^{-1}\right)$; (5) metsulfurom-metílico $\left(6 \mathrm{~g}\right.$ i.a. ha $\left.{ }^{-1}\right)$ e (6) testemunha, sem aplicação de herbicidas. No segundo experimento, os tratamentos foram: (1) saflufenacil (70 g i.a. ha $\left.{ }^{-1}\right)$; (2) carfentrazona-etílica (20 g i.a. ha $\left.{ }^{-1}\right)$; (3) flumioxazim (120 g i.a. ha $\left.{ }^{-1}\right)$; (4) metsulfurom-metílico (6 g i.a. ha-1), todos esses tratamentos com uma sequencial de indaziflam $\left(75 \mathrm{~g}\right.$ i.a. ha $\left.{ }^{-1}\right)$ aos 21 dias após a aplicação dos tratamentos (DAT) dos pósemergentes; (5) testemunha, sem aplicação de herbicidas. No primeiro experimento, os herbicidas saflufenacil e flumioxazim, apresentaram as melhores porcentagens de controle na pós-emergência com 90 e 85,5\% respectivamente, aos 7 DAT, mantendo o controle superior a $80 \%$ até os 21 DAT. No segundo experimento, os tratamentos saflufenacil e flumioxazim com sequencial de indaziflam, apresentaram controle de 80 e 82,5\% respectivamente aos 28 DAA (Dias Após a Aplicação). Os herbicidas saflufenacil e flumioxazim, representam uma opção para o controle de C. benghalensis em pós emergência e favorecem o desempenho do herbicida indaziflam aplicado de forma sequencial.
\end{abstract}

Termos para indexação: Plantas daninhas, herbicida, indaziflam.

\section{INTRODUCTION}

One of the main forms of weed handling in coffee crop is the use of herbicides. About $85 \%$ of these applications are carried out through glyphosate, a non-selective, non-residual systemic herbicide with a broad spectrum of control (Ronchi \& Silva, 2014). The inconvenience of this handling is the necessity of several application of glyphosate during the crops conduction which results in selection of resistant biotypes and/or tolerant plants (Chistoffoleti et al., 2016).

In this scenario, Commelina benghalensis L. (Benghal dayflower) has become a weed frequently reported as weeds in coffee plantations, due to the successive applications of glyphosate (Vargas et al., 2001; Santos et al., 2001; Oliveira et al., 2009). This situation occurs because this species presents tolerance to the herbicides enolpiruvil shikimate phosphate synthase (EPSPs),

1,2,3,4 Centro Universitário da Fundação de Ensino Octavio Bastos/UNIFEOB - Av. Dr. Octávio da Silva Bastos, 2439 - Jd. Nova São Paulo - 13.874-601 - São João da Boa Vista - SP - paulo.vinicius@unifeob.pro.br,gustavo.barbosa@sou.unifeob.edu.br, andrea.ferrari@sou.unifeob.edu.br, smtronquini@gmail.com

${ }^{5}$ Universidade Federal de São Carlos/UFSCar - Centro de Ciências Agrárias/CCA - Departamento De Recursos Naturais e Proteção Ambiental/DRNPA - Cx. 153 - 13.604-900 - Araras - SP - pamonque@cca.ufscar.br 
through the chemical composition of the waxes present on the leaf surface, resulting in differential absorption of glyphosate, which is considered slow, and as well as the differential metabolism of glyphosate converting to aminomethylphosphonic acid (AMPA) (Monquero et al., 2004a; Monquero et al., 2004b and Carvalho et al., 2013).

The plants of $C$. benghalensis present better vegetative development in areas with high humidity and temperatures (Kissmann \& Groth, 1999; Lorenzi, 2008), in addition to soils with a higher percentage of organic matter, these characteristics favor the perennially of the species (Voll et al., 2002; Kissmann \& Groth, 1999), providing the propagation of plants in coffee plantations. This process is favored by the biology of the plants of the genus Commelinaceae spp., because pieces of branches left in the soil resist adverse conditions for a long period, such as: water stress, low intensity luminosity and when these limiting conditions are overcome, budding occurs (Ronchi \& Silva, 2003; Ronchi et al., 2014; Oliveira et al., 2009).

In this way, $C$. benghalensis finds favorable conditions for its full development, causing strong interference in the coffee crops, especially in young coffee plantation (Dias et al., 2005). This infestation can be even more damaging when it is established in the period from October to March (stage of grains filling) and in plantation in formation when located in the projection of the coffee canopy (Silva et al., 2018).

This occurs because $C$. benghalensis can affect coffee plantations in the following ways: (1) Interference in the harvesting process (mechanized or manual) (Dias et al., 2005; Carvalho et al., 2013); (2) It damages the photosynthetic apparatus of coffee plants, because due to the climbing habit, the plants of $C$. benghalensis are coiled in the coffee plants, covering its leaf surface and affecting its photosynthetic apparatus (Ronchi et al., 2002a); (3) Through direct competition for resources within the same space (Ronchi \& Silva, 2003; Ronchi \& Silva, 2014) and (4) by affecting other stages of the coffee production system (Oliveira et al., 2009; Ronchi et al., 2016).

The plants of $C$. benghalensis are not efficiently controlled by glyphosate, the main herbicide used in the coffee crop (Dias et al., 2013). However, other herbicides post-emergent registered for cultivation can be used to control $C$. benghalensis. Among the options we can mention: carfentrazone, glufosinate, metsulfuron (register only for the post-emergence control of Bidens pilosa), flumioxazin (also presents pre-emergent action with residual) and saflufenacil (Agrofit, 2018). These products present a recommendation of jet application directed in between coffee lines, avoiding the contact of the herbicide with the crop, and minimizing possible phytotoxics effects inherent to selectivity (Rodrigues \& Almeida, 2018).

Except for flumioxazin, the other herbicides mentioned above have low and/or none residual to control new weed germination flows (Rodrigues \& Almeida, 2018). In this sense, the positioning in coffee plantation of pre-emergent herbicides works as an efficient chemical control tool, since the prolonged residual in the field can guarantee the reduction of the seed bank of weeds of difficult control, such as $C$. benghalensis.

The indaziflam is a herbicide registered for coffee crop in the year 2016, which presents as the mechanism of action the inhibition of cellulose biosynthesis and belonging to the chemical category "alkylazine" (Tompkins, 2010). This product presents high efficiency in weed control, with a wide spectrum of control on monocotyledonous and eudicotyledonous species, even at low doses (Brosnan et al., 2011; Brosnan et al., 2012).

In Brazil, indaziflam in the coffee crop should be positioned in rainy season, with application in humid soil and free of clods, directed in the lines of the crop through a directed jet in pre-emergence modality of weeds. This herbicide should be applied only in coffee plantations from 3 years of age, that is, with plants in full production and that have a woody stem, lignified with the bark around the stem. Another precaution in relation to indaziflam is that its application should occur with a minimum interval of 12 months. Indaziflam presents record for the control of $C$. benghalensis, thus, its application in the preemergence condition, may provide residual for the control of new germination flows of this species (Rodrigues \& Almeida, 2018).

Considering the above, the aim of this present study was to evaluate the control of $C$. benghalensis by herbicides applied in the postemergence and in pre-emergent sequentially in the infesting weed in the coffee crop.

\section{MATERIAL AND METHODS}

The experiments were carried out in the field on a commercial coffee production farm, located in the municipality of Caconde, in the state of São Paulo (SP), Brazil (21 $27^{\prime}$ S e $\left.46^{\circ} 35^{\prime} \mathrm{O}\right)$, 
which presents according to the Koppen climate classification, hot climate and mild climate CWA type, with average annual rainfall of $1579 \mathrm{~mm}$, which is higher in summer than in winter. The average annual temperature is $20.0^{\circ} \mathrm{C}$ (Köppen \& Geiger, 1928).

The experiments were carried out in an area cultivated with Arabian coffee (Coffea arabica) of the Red Catuaí variety, in a 14 -year - old crop, composed of 3.000 coffee plants conducted in a rainfed system. The experimental area consisted of $1.500 \mathrm{~m}^{2}$ totalizing 500 plants. Soil chemical analysis was performed (as presents in table 1). The phytosanitary administration (pests and diseases), fertilization and liming were carried out normally, according to the recommendation of bulletin 100 for the full development of the crop (Maia \& Furlani, 1996).

Before the installation of the experiment, a phytosociological survey of weeds was carried out, aiming to establish the population survey through methodology of the square inventory. The plants of $C$. benghalensis were the predominant plants in the area, with a density of $42.8 \mathrm{pl} . \mathrm{m}^{-2}$.

Two experiments were carried out aiming at the control of $C$. benghalensis, the first one related to control with herbicides in the post-emergence condition without the use of sequential herbicide and the second with application of herbicides in post-emergence with a sequential application of pre-emergent herbicide (indaziflam - Alion - $75 \mathrm{~g}$ i.a. ha-1 ${ }^{-1}$ ). For both experiments, the experimental design was completely randomized, and the experimental area consisted of two rows of coffee, each containing $10 \mathrm{~m}$ in length and the plots were $2 \mathrm{~m}$ wide and $3 \mathrm{~m}$ long, totaling an area per plot of $6 \mathrm{~m}^{2}$, with four replications.

For post-emergence controlling, the treatments used are available on Table 2. The herbicide treatments were applied when the plants of C. benghalensis resented 10 leaves and 12 lateral branches (beginning of flowering) according to the scale BBCH 51 used to classify the phenology of C. benghalensis (Dias et al., 2013).

In the experimental related to the sequential application of herbicides, all treatments were herbicide application in the post-emergence period, when the plants were in a flowering start the phenological stage- BBCH 51 (Dias et al., 2013), and 10 days after application - DAA, the sequential application of the indaziflam herbicide in pre-emergence condition was performed. The treatments related to the application of experiment 2 are presented in table 3 .

The treatments were applied through a constant pressurized $\mathrm{CO}_{2}$ pressure sprayer with fan-type tips XR 110.02, pressure of $2.0 \mathrm{kgf} \mathrm{cm}^{-2}$, with a syrup volume of $150 \mathrm{~L} \mathrm{ha}^{-1}$. At the time of application of post-emergent herbicides (from both experiments) the environmental conditions were favorable, with a temperature of $23.5^{\circ} \mathrm{C}$, the air humidity of $60 \%$ and the wind speed of $3.2 \mathrm{~km} \mathrm{~h}^{-1}$.

TABLE 1 - Result of soil chemical analysis of the experimental area $(0-20 \mathrm{~cm})$.

\begin{tabular}{lcccccccccccc}
\hline pH $\left(\mathrm{CaCl}_{2}\right)$ & Al & $\mathbf{H}+\mathbf{A l}$ & $\begin{array}{c}\mathbf{P} \\
(\text { resin) }\end{array}$ & $\mathbf{K}$ & $\mathbf{C a}$ & $\mathbf{M g}$ & $\mathbf{S B}$ & $\mathbf{C T C}$ & $\mathbf{V}$ & Argil & Silt & Sandy \\
\hline 4.7 & $<1.5$ & 3.0 & 13.0 & 5.4 & 44.0 & 9.0 & 58.4 & 112.4 & 65 & 58.0 & 6.0 & 21.0 \\
\hline
\end{tabular}

Units: Al, H+Al, K, Ca, Mg, SB e and CTC $\left(\mathrm{mmol}_{\mathrm{c}} \mathrm{dm}^{-3}\right) ; \mathrm{P}(\mathrm{resin})\left(\mathrm{mg} \mathrm{dm}^{-3}\right) ; \mathrm{V}$, argil, silt, sandy $(\%)$.

Source: Brazilian Institute of Analyzes.

TABLE 2 - Treatments applied in post-emergence condition in the coffee crop to control the Commelina benghalensis.

\begin{tabular}{lcc}
\hline Treatments & Commercial name & ${\text { Applied dose } \mathbf{g} \text { i.a } \mathbf{~ h a}^{-1}}^{\mathbf{1}}$ \\
\hline T1 - Saflufenacil + Mineral Oil & Heat & $70+0.5 \%$ \\
T2 - Glufosinate + Mineral Oil & Finale & $400+0.25 \%$ \\
T3 Carfentrazone + Mineral Oil & Aurora & $20+0.5 \%$ \\
T4 - Flumioxazin + Mineral Oil & Flumyzin 500 & $120+0.25 \%$ \\
T5 - Metsulfuron + Mineral Oil & Ally & $6+0.1 \%$ \\
T6 - Witness (no treament) & - & - \\
\hline
\end{tabular}


TABLE 3 - Treatments applied in post-emergence condition in the coffee crop to control Commelina benghalensis.

\begin{tabular}{ccc}
\hline Treatments & Commercial name & Applied dose g i.a ha $^{-1}$ \\
\hline T1 - Saflufenacil seq. Indaziflam + Mineral Oil & Heat - Alion & $70+75+0.5 \%$ \\
T2 - Carfentrazone seq. Indaziflam + Mineral Oil & Aurora - Alion & $50+75+0.5 \%$ \\
T3 - Flumioxazin seq. Indaziflam + Mineral Oil & Flumyzin 500 - Alion & $120+75+0.25 \%$ \\
T4 - Metsulfuron seq. Indaziflam + Mineral Oil & Ally - Alion & $6+75+0.5 \%$ \\
T5 -Witness ( no treatment) & & - \\
\hline
\end{tabular}

At the time of application of the indaziflam herbicide sequentially (pre-emergent herbicide) the environmental conditions of the application were: temperature of $25^{\circ} \mathrm{C}$, air humidity of $53 \%$ and wind speed of $2.8 \mathrm{~km} \mathrm{~h}^{-1}$.

The control of Commelina benghalensis was evaluated at 7, 14 and 21 days after application of the treatments (DAT), for the control experiment in the post-emergence condition. In the experiment with sequential application, after application of the indaziflam herbicide (10 DAT of post-emergence treatments), control evaluations were performed at 7, 14, 21 and $28 \mathrm{DAA}$, by the visual evaluation method, assigning notes, in percentage of control in relation to the witness (no treatment). The scale used ranged from 0 (no visible damage) to $100 \%$ (plant death). This evaluation was based on the visual control scale of ALAM (1974).

The data were submitted to analysis of variance by the $\mathrm{F}$ test $(5 \%)$, and the means were compared by means of the Tukey test, using the Agroestat statistical software program (Barbosa \& Maldonato, 2009).

\section{RESULTS AND DISCUSSION}

The data of control C. benghalensis through the application of post-emergent herbicides are presented in table 4 . In the first evaluation at 7 (DAT) the saflufenacil and flumioxazin, presented control of 90 and $86.25 \%$ respectively. These percentages of control were increasing up to 14 DAT and subsequently decreased to 21 DAT, when these herbicides, caused control of $81.25 \mathrm{e}$ $80 \%$, respectively.

In relation to the other herbicides, all of them were inefficient in the control of $C$. benghalensis (table 4). The carfentrazone provided a $72.5 \%$ control at 14 DAT, but this result showed up a drop at 21 DAT, resulting in a $52.5 \%$ control. The treatments, carfentrazone, metsulfuron and glufosinate presented control percentages of $C$. benghalensis of 37.5 and $35 \%$, respectively, at 21 DAT. In these three treatments, carfentrazone, metsulfuron and glufosinate, an expressive regrowth and increase in the population density of C. benghalensis plants at 21 DAT were observed.

The control of percentages higher than $80 \%$, obtained in the application of saflufenacil and flumioxazin treatments can be justified by the association of three factors: (1) the mechanism of action of these products, since both are contact herbicides and PROTOX inhibitors; in the postemergence conditions are absorbed by stems and leaves of $C$. benghalensis plants, which have fast and accelerated necrotic symptoms when the plants are exposed to light (Carvalho et al., 2016); (2) Due to the climatic conditions of the experimental area at the time of the experiment (December and January), with high incidence of light, being composed of long days, with photoperiod over 13 to 14 hours of effective light (Camargo, 1985), and (3) Due to the geographical location of the high-altitude site $(1056 \mathrm{~m})$ with exposure to solar radiation towards the east, providing light from sunrise to sunset.

This association of factors for the application of the herbicides saflufenacil and flumioxazin, resulted in expressive and accelerated symptoms through the formation of irregular necrotic spots in the leaf limb (burns), mainly in the apical regions. However, it should be noted that both saflufenacil and flumioxazin did not present residual for control of $C$. benghalensis, and this fact can be observed by the gradual decrease of control percentages during the evaluation periods (7, 14 e 21 DAT).

This accelerate increase of regrowth and/ or germination of a new germination flow of $C$. benghalensis may also have been influenced by the intense rainfall and high temperatures during the conduction of the experiment. 
TABLE 4 - Control of Commelina benghalensis at 7, 14 e 21 days after application of pre-emergence herbicide treatment (DAT).

\begin{tabular}{|c|c|c|c|}
\hline \multirow[t]{2}{*}{ Treatments } & \multicolumn{3}{|c|}{ Evaluation Period (DAT) } \\
\hline & 7 & 14 & 21 \\
\hline Saflufenacil & $90.00 \mathrm{aA}$ & $93.75 \mathrm{aA}$ & $81.25 \mathrm{Aa}$ \\
\hline Glufosinate & $30.75 \mathrm{bcA}$ & $36.25 \mathrm{bA}$ & $37.5 \mathrm{cA}$ \\
\hline Carfentrazone & $53.75 \mathrm{bA}$ & $72.5 \mathrm{aA}$ & $52.5 \mathrm{bcA}$ \\
\hline Flumioxazin & $86.25 \mathrm{aA}$ & $82.5 \mathrm{aA}$ & $80 \mathrm{aA}$ \\
\hline Metsulfuron & $12.50 \mathrm{cA}$ & $27.5 \mathrm{bA}$ & $35 \mathrm{cA}$ \\
\hline $\mathrm{MSD}_{\text {Trat }}=27.6$ & & & $\mathrm{MSD}_{\text {ava }}=23.6$ \\
\hline$\underline{\mathrm{F}_{\text {trat }}}=50.7 * *$ & & & $\mathrm{~F}_{\text {trat } \mathrm{x} \text { ava }}=\mathrm{NS}$ \\
\hline \multicolumn{4}{|c|}{ C.V. $(\%)=23.7$} \\
\hline
\end{tabular}

In addition to these aspects, the coffee cultivation system presents a large line spacing which allows the constant solar incidence in the spaces that are not shaded by projection of the coffee's top, culminating in a continuous flow germination of weeds in coffee plantations, between harvest intervals, this germination dynamics, results in bush competition with crop besides interfering in other crop administration stages, such as fertilization, application of insecticides and fungicides, cultivation of intercropping, etc. (Ronchi et al.,2014; Ronchi et al.,2002a; Silva \& Ronchi, 2008).

Martins et al. (2012) carried out a field experiment aiming at the control of C. benghalensis. The application of herbicide treatments: saflufenacil + glyphosate and saflufenacil $+($ glyphosate + imazethapyr $)$, provided a control means of $70 \%$ and $81.7 \%$ respectively, at 14 days after application (DAA), which remained constant during 45 days of evaluation. However, the authors report the inefficiency of saflufenacil in the control of $C$. benghalensis applied in isolation, at $45 \mathrm{DAT}$, to the detriment of regrowth, reinforcing the hypothesis of the need for postemergence sequential applications and /or the use of pre-emergent products, sequentially.

Morichetti et al. (2012) applied the saflufenacil herbicide at doses 12.25 and $50 \mathrm{~g}$ i.a. ha $^{-1}$ in three different heights of $C$. benghalensis $(2-5 \mathrm{~cm}, 5-10 \mathrm{~cm}$ and $10-15 \mathrm{~cm})$. At the height of $2.5 \mathrm{~cm}$, in the evaluation period of $7 \mathrm{DAT}$, all doses were effective in the control of this weed, with percentages of 87.93 and $94 \%$ for doses of
12,25 and $50 \mathrm{~g}$ i.a. ha $^{-1}$, respectively and at 28 DAT, no dose reached the control percentage of $80 \%$. At the height of $5-10 \mathrm{~cm}$, this same behavior was observed.

At the height of $10-15 \mathrm{~cm}$, saflufenacil was not effective in the control of Commelina benghalensis, at any dose and period of evaluation. Freitas et al. (2018) sowed the vegetative propagation organs of $C$. benghalensis in plastic vases, which were kept in a greenhouse and 60 days after transplant, the plants were pruned and standardized in $10 \mathrm{~cm}$ of height, 30 days after pruning, when the stems reached approximately 25 $\mathrm{cm}$ in length, the application of flumioxazin (45 g i.a. ha $^{-1}$ ) occurred in the post-emergence condition. The control reduction was observed throughout the evaluation days, with control percentages of $30 \%$, $63.33 \%, 26.66 \%$ and $16.66 \%$, for the periods of 7 , 14,28 and 60 DAA, respectively.

Pereira and Carmona (2000) observed an excellent control of $C$. benghalensis at 14 and 28 days after application of the treatments (DAT), by the application of flumioxazin associated with mineral oil, at doses of 30,40 and $50 \mathrm{~g}$ i.a. ha ${ }^{-1}$, with percentages of 91,92 and $90 \%$, respectively, at 28 DAT. Under these conditions, a delay in the appearance of broadleaved weeds was also observed. This efficacy in the control of flumioxazin in post-emergence condition can be justified by the higher affinity for lipophilic materials of this herbicide (Kow), in this way, when applied on the leaves of $C$. beghalensis, facilitating the process of absorption by lipophilic affinity (Monquero et al., 2016). 
Although flumioxazim also presents recommendation for controlling in the preemergence condition of weeds in the coffee crop, no residual was observed. It possibly happened because the infestation of $C$. benghalensis in the experimental area presented high density (Density plants $\mathrm{m}^{-2}=42.8$ and Relative density $\%=82.3$ ) covering the soil. This situation associated with the high Kow value of flumioxazin (2.55), might have resulted in the interception and/or absorption of this herbicide by $C$. beghalensis plants, decreasing the amount of product that effectively reached the soil.

That way, aiming at residual flumioxazin action, the ideal would be to establish a control effect of the emergent plants in the field, thus leaving the soil exposed so that a greater amount of herbicide reaches the soil, resulting in its preemergent action of this herbicide.

However, flumioxazin has application restrictions in some coffee plantations, to the detriment of the certification system to produce special coffees, where not all agrochemicals can be used in crop management (UTZ, 2015). In this sense, flumioxazin is included in the List of Pesticides Banned and List of Pesticides in Observation of UTZ, because it presents reproductive toxicity and adverse effects for sexual function and fertility in adult, men and women, as well as toxicity on the development of the descendants, according to the regulation 1272/2008/EC of the EU GHS (UTZ, 2015).

The $C$. benghalensis plants were in an advanced phenological stage of development (BBCH 51) (Dias et al., 2013). This hindered the control and action of some herbicides that could have presented better performance, such as ammonium glufosinate, carfentrazone and metsulfuron. This occurs because plants with an advanced phenological stage become difficult to control and decrease the effectiveness of herbicide control whereas early stage plants facilitate control handling (Hess et al., 1997).

In relation to glufosinate, for control to be adequate, applications should occur in plants with up to 4 leaves. However insufficient control by metsulfuron can be justified by the absence of registration of this product for the control of Commelina ssp in coffee crop (Rodrigues \& Almeida, 2018). Ronchi et al. (2002b), applying the association of glyphosate + metsulfuron (720 +4.0 g i.a. ha ${ }^{-1}$ ), after 120 of the C. benghalensis transplant, obtained a control percentage of $50 \%$ at 28 DAT.
This behavior was verified by Souza et al. (2001), which aimed to control benghal dayflower (C. benghalensis) with 6 to 7 leaves, obtained effective control of this species through the association of carfentrazone + glyphosate, at doses of $30+1200,40+1200$ and $50+1200$ g i.a. ha- ${ }^{-1}$, with 100,98 and $85 \%$ control respectively. Thus, the application of carfentrazone at the beginning of C. benghalensis development could have resulted in effective control. However, this was not the case in this experiment, since the plants were in a flowering phenological stage (BBCH 51) (Dias et al., 2013).

Therefore, the $C$. benghalensis presents high adaptation and difficult in being controlled in productive coffee systems. In all application of post-emergent herbicides, they culminated in regrowth of $C$. benghalensis and/or germination of a new flow of this weed. In addition, the use of C. benghalensis has been shown to be associated with the need for other post-emergence and/or sequential applications of pre-emergent herbicides (Voll, et al. 2002).

In relation to the experiment 2 , the results can be observed in Table 5. The saflufenacil and flumioxazin treatments applied in post-emergence period and with indaziflam sequencing, provided the best results, with 82.5 and $80 \%$ of control, respectively. The other treatments: carfentrazone and metsulfuron with indaziflam sequencing were ineffective in the control of $C$. benghalensis, with control percentages of 63.75 and $65 \%$, respectively.

The fact that saflufenacil and flumioxazin provide good control in the initial post - emergence, reduced the soil cover by $C$. benghalensis plants, which may have provided a lower absorption of indaziflam by this plant, allowing a greater amount of herbicide reached the soil, for its action as preemergent and allowing a residual for control.

The herbicides carfentrazone and metsulfuron do not provide a reduction in the density of infestation of $C$. benghalensis, resulting in the continuity of its vegetative development, and consequently in the permanence of the ground cover by this weed.

Thus, post-emergence treatments in which C. benghalensis was not efficiently controlled did not result in a reduction in the infestation density present in the area, negatively impacting the efficacy of indaziflam sequentially positioned preemergence. 
TABLE 5 - Control of $C$. benghalensis at 7, 14 and 21 days after application of indaziflam

\begin{tabular}{ccccc}
\hline \multirow{2}{*}{ Treatments } & \multicolumn{3}{c}{ Evaluation Period After Indaziflam Sequential (DAA) } \\
\cline { 2 - 5 } & $\mathbf{7}$ & $\mathbf{1 4}$ & $\mathbf{2 1}$ & $\mathbf{2 8}$ \\
\hline Saflufenacil / Indaziflam & $61.25 \mathrm{a} \mathrm{AB}$ & $62.5 \mathrm{aB}$ & $65 \mathrm{abB}$ & $82.5 \mathrm{aA}$ \\
Carfentrazone / Indaziflam & $52.5 \mathrm{abA}$ & $58.75 \mathrm{aA}$ & $59.5 \mathrm{abA}$ & $63.75 \mathrm{bA}$ \\
Flumioxazin / Indaziflam & $63.75 \mathrm{aB}$ & $68.75 \mathrm{aAB}$ & $70 \mathrm{aAB}$ & $80 \mathrm{aA}$ \\
Metsulfuron / Indaziflam & $45 \mathrm{bB}$ & $60 \mathrm{aA}$ & $62.5 \mathrm{abA}$ & $65 \mathrm{bA}$ \\
\hline $\mathbf{M D S}_{\text {Trat }}=7.14$ & \multicolumn{3}{c}{$\mathbf{M S D}_{\text {ava }}=14.29$} \\
\hline $\mathbf{F}_{\text {trat }}=13.75^{* *}$ & \multicolumn{2}{c}{$\mathbf{F}_{\text {ava }}=14.76$} & \multicolumn{2}{c}{$\mathbf{F}_{\text {trat x ava }}=\mathrm{NS}$} \\
\hline
\end{tabular}

Sequentially (DAA) herbicide and with indaziflam herbicide as sequential; $* *$ (significant at the $1 \%$ probability level by the F test); NS = Not significant; C.V. (coefficient of variation); MSD (minimum significant difference). Means followed by lower case letters in the column and upper case in the row do not differ by Tukey test at $5 \%$ significance.

Although indaziflam has a record for initial post-emergence in other countries, as in the United States (Shaner, 2014), in Brazil there is no record and /or recommendation of control in the initial weed post-emergence condition (Rodrigues \& Almeida, 2018). In this experiment it was possible to observe that in the sequential application of indaziflam in sites with plants, that is, where the control in the post-emergence application was not effective, it resulted in leaves with purplishness, reduced plant size and some cases necrotic spots in the foliar surface, however, throughout the evaluation periods the plants gradually recovered the symptoms, probably by the metabolization of the herbicide by $C$. benghalensis.

It should be noted that indaziflam has a high Kow value (2.80) which may have favored its uptake by $C$. benghalensis plants (Kaapro \& Hall, 2012). Therefore, the best positioning of indaziflam for $C$. benghalensis control is through the application of this product to areas with a lower density of this weed, or through the application of post-emergence herbicides that result in a decrease in $C$. benghalensis density for a sequential application of indaziflam.

This situation provides a larger contact surface of the exposed soil, allowing the indaziflam applied sequentially to arrive in enough quantity to control different germination flows of $C$. benghalensis. This fact becomes explicit, through the results obtained in the application of the herbicides saflufenacil and flumioxazin, where both obtained a good control in the postemergence, but rebroared without the sequential application of indaziflam. On the other hand, these indaziflam sequenced products provided control near $80 \%$ at 28 days after the sequential application of the pre-emitting herbicide, with gradual evolution of the control percentages, due to the absence of regrowth and the interruption of the vegetative development of $C$. benghalensis.

Thus, the rapid control obtained in the post-emergence application of the PROTOX inhibitor herbicides, saflufencil and flumioxazin, contributed to the adequate performance of indaziflam, as they maintained the exposed soil without the cover of weeds for a longer period, favoring action of the indaziflam positioned in the pre-emergency.

\section{CONCLUSION}

PROTOX inhibitor herbicides saflufenacil and flumioxazin had better post-emergence results. In relation to the pre-emergence control, it was concluded that the best performance of indaziflam is associated to applications of these products in areas with low weed density and consequently with greater surface area of exposed soil, a fact that was obtained in the positioning in the post-emergence of saflufenacil and flumioxazin herbicides with sequential application of indaziflam.

\section{REFERENCES}

ASOCIATION LATINOAMERICANA DE MALEZAS. Recomendaciones sobre unificación de los sistemas de evaluación em ensayos de control de malezas. ALAM, Bogotá, v. 1, p. 3538, 1978. 
BARBOSA J.C. \& MALDONADO JÚNIOR W. (2009) AgroEstat versão 1.0 - Sistema de análises estatísticas de ensaios agronômicos. Universidade Estadual Paulista, Campus de Jaboticabal, SP.

BROSNAN, J.T.; Mc CULLUOGH, P.E.; BREEDEN, G.K. Smooth crabgrass control with indaziflam at various spring timings. Weed Technology, v.25, n.3, p.363-366, July. 2011.

BROSNAN, J.T. et al. Pre and post emergence annual bluegrass control with indaziflam. Weed Technology, v.26, n.1, p.48-53, January. 2012.

CAMARGO, A. P. Florescimento e frutificação de café arábica nas diferentes regiões cafeeiras do Brasil. Pesquisa Agropecuária Brasileira, Brasília, v.20, n.7, p. 831-839, July. 1985.

CARVALHO, S, J, P.; NETTO, A. G. . Resistência de plantas daninhas aos herbicidas inibidores da protox (Grupo E). In: P.J. Christoffoleti; M. Nicolai. (Org.). Aspectos de Resistência de Plantas Daninhas a Herbicidas. Piracicaba-SP, $4^{\mathrm{a}}$ ed., v. p. 11-31, 2016.262p.

CARVALHO, L. B. et al. Sourgrass densities affecting the initial growth and macronutrient content of coffee plants. Planta Daninha, Viçosa, v. 31, n. 1, p. 109-115, Jan./Mar. 2013.

CHRISTOFFOLETI, P.J. et al. Resistência de plantas daninhas a herbicidas: termos e definições importantes. In: P.J. Christoffoleti; M. Nicolai. (Org.). Aspectos de Resistência de Plantas Daninhas a Herbicidas. $4^{\mathrm{a}}$ ed.:, 2016, v. , p. 11-31.

DIAS, A.C.R. et al. Fenologia da trapoeraba como indicador para tolerância ao herbicida glyphosate. Planta Daninha, Viçosa-MG, v. 31, n. 1, p. 185-191, Jan./Mar. 2013.

DIAS, T.C.S. et al. Períodos de interferência de Commelina benghalensis na cultura do café recémplantada. Planta Daninha. Viçosa-MG, v. 23, n. 3, p. 398-404, Dez/Jan. 2005.

FREITAS, N.M. et al. Herbicide Mixtures To Control Dayflowers And Drift Effect On Coffee Cultures. Planta daninha. Viçosa-MG, v.36:e018169798. 2018.

HESS, M. et al. Use of the extended BBCH scale-general for the descriptions of the growth stages of mono and dicotyledonous weed species. Weed Research. v. 37, n. 6, p. 433-441. June/July. 1997.
KAAPRO, J.; HALL, J. Indaziflam - a new herbicide for pre-emergent control of weeds in turf, forestry, industrial vegetation and ornamentals. Pakistan Journal of Weed Science Research, v.18, p.267-270, Special issue. 2012.

KISSMANN, K. G.; GROTH, D. Plantas infestantes e nocivas. 2. ed. São Bernardo do Campo: Basf, 1999. p. 152-156, 278-284.

KÖPPEN, W.; GEIGER, R. Klimate der Erde. Gotha: Verlag Justus Perthes. Wall-map 150cmx200cm.1928.

LORENZI, H. Plantas Daninhas do Brasil: terrestres, aquáticas, parasitas e tóxicas. 4. Ed. Nova Odessa, SP: Instituto Plantarum, 2008.640p.

MAIA, N. B.; FURLANI, A. M. C.; Especiarias, aromáticas e medicinais. Boletim Técnico do Instituto Agronômico de Campinas, Campinas, n. 100, p. 7576, 1996.

MARTINS, D. et al. Manejo químico de espécies de trapoeraba com aplicação isolada e em mistura de diferentes herbicidas. Revista Caatinga, Mossoró, v. 25, n. 2, p. 21-28. Mar/Jun. 2012.

MONQUERO, P. A. et al. Caracterização da superfície foliar e das ceras epicuticulares em Commelina benghalensis, Ipomoea grandifolia e Amaranthus hybridus. Planta Daninha, Viçosa-MG, v. 22, p. 203210.Abr/Jun. 2004a.

MONQUERO, P. A. et al. Absorção, translocação e metabolismo do glyphosate por plantas tolerantes e suscetiveis. Planta Daninha, Viçosa, v. 22, n.3, p. 445451.July/Sept. 2004b.

MONQUERO, P.A. et al. Controle pelo glyphosate e caracterização geral da superfície foliar de Commelina benghalensis, Ipomoea hederifolia, Richardia brasiliensis e Galinsoga parviflora. Planta Daninha, v. 23, n. 1, p. 123-132. Jan/Mar. 2016.

MORICHETTI, S. et al. Weed Management and Peanut Response from Applications of Saflufenacil. Weed Technology, 26(02), 261-266. April. 2012.

OLIVEIRA, A.R. et al. Controle de Commelina benghalensis, $C$. erecta e Tripogandra diuretica na cultura do café. Planta Daninha, Viçosa-MG, v. 27, n. 4, p. 823-830. Out/Dez. 2009. 
PEREIRA, R. C.; CARMONA, R. Eficácia do herbicida flumioxazin, isolado e em mistura com sulfosate, no manejo de plantas daninhas em plantio direto de soja. Revista Brasileira de Herbicidas, Brasilia-DF, v.l, n.2, p. 113 -117. Apr/May. 2000.

RODRIGUES, B.N.; ALMEIDA, F.S.; Guia de herbicidas. $7^{\mathrm{a}}$ ed., Londrina, 2018. 697p.

RONCHI, C. P. et al. Manejo de plantas daninhas em lavouras de café. Viçosa: Universidade Federal de Viçosa, 2002a. 94 p.

RONCHI, C. P. et al. Eficiência de misturas de herbicidas no controle de trapoerabas. In: XXIII Congresso Brasilieiro da Ciência das Plantas Daninhas, 2002, Gramado, RS. Resumos. Londrina, PR: SBCPD, 2002b. v. 23. p. 474-474.

RONCHI, C.P.; SILVA, A.A. Tolerância de mudas de café a herbicidas aplicados em pós-emergência. Planta Daninha, Viçosa - MG, vol.21, n.3, pp.421-426. July/ Sep. 2003.

RONCHI, C. P. et al. A. Épocas de poda e a produtividade de clones de café conilon. In: 34 Congresso Brasileiro de Pesquisas Cafeeiras, 2008, Caxambu. Anais. Varginha-MG: MAPA/PROCAFÉ, 2008. v. 34.

RONCHI, C.P. et al. Manejo de plantas daninhas na cultura do café. In: Patrícia Andrea Monquero. (Org.). Manejo de plantas daninhas nas culturas agrícolas. 1ed.São Carlos: RiMa Editora, 2014, v., p. 132-154.

RONCHI, C.P. et al. Manejo Integrado de plantas daninhas. In: Romário Gava Ferrão; Aymbiré Francisco Almeida da Fonseca; Maria Amélia Gava Ferrão; Lúcio Herzog De Muner. (Org.). Café Conilon: $2^{\mathbf{a}}$ edição atualizada e ampliada (ISBN 978-85-89274-26-5). 2ed.Vitória-ES: Incaper, 2016, v, p. 383-394.

SANTOS, I. C. et al. Eficiência de glyphosate no controle de Commelina benghalensis e Commelina diffusa. Planta Daninha, v. 19, n. 1, p. 135-143. Jan/Mar. 2001.
SHANER, D.L. Herbicide Handbook. Weed Science Society of America, Lawrence, 10th Edition, 513 p. 2014.

SILVA, A. A.; RONCHI, C. P. Manejo e controle de plantas daninhas em café. In: VARGAS, L.; ROMAN, E. S. (Org.). Manual de manejo e controle de plantas daninhas (ISBN: 9788589873901). 2ed.Passo Fundo: Embrapa Trigo, 2008, v., p. 417-465.

SILVA, C. A. da et al. Chemical control of Conyza canadensis (L.), in mixtures of herbicides with glyphosate in coffee crop. Coffee Science, Lavras, v. 13, n. 2, p. 252 - 256. Apr./Jun. 2018.

SISTEMA DE AGROTÓXICOS FITOSSANITÁRIOS (AGROFIT). Available in: < http://agrofit.agricultura. gov.br/agrofit_cons/principal_agrofit_cons $>$ Access in: 31 out. 2018.

SOUZA, L. S. et al. Eficácia do carfentrazone-ethyl em mistura com glyphosate no controle de trapoeraba na cultura do café. Revista Brasileira de Herbicidas. v. 2, n. 1, p. 19-22. Jan./Mar. 2001.

TOMPKINS, J. Pesticide fact sheet: indaziflam. United States, Environmental Protection Agency 2010. Available in: http://www.epa.gov/opp00001/chem search/reg_actions/registration/fs_PC-080818_26Jul-10.pdf.> Access in: 18 de Setembro de 2018.

UTZ. LISTA DE PESTICIDAS BANIDOS e LISTA DE PESTICIDAS EM OBSERVAÇÃO pela UTZ Certified 2015. Available in:: < https://utz.org/whatwe-offer/certification/products-we-certify/coffee/ $>$. Access in: 04 fev. 2019.

VARGAS, L. et al. Resistência de plantas daninhas a herbicidas. Viçosa, MG: Jard, 2001. 131 p.

VOLL, E. et al. Aspectos fisiológicos da germinação de sementes de trapoeraba (Commelina benghalensis L.). Revista Brasileira de Sementes. v. 24, n. 1, p. 162168. Jan/Mar. 2002. 